\title{
As contas dos escravos numa economia agrária: clientes de uma casa de comercial no interior de Santa Catarina
}

\author{
Renato Leite Marcondes ${ }^{1}$
}

\section{Resumo}

Discutimos os negócios dos escravos a partir das contas correntes como clientes de uma casa comercial em uma economia voltada para o mercado interno ao final do período escravista, evolvendo débitos e créditos, dinheiro e mercadorias. Os cativos forneceram milho e feijão e compraram um leque amplo de produtos, compreendendo alimentos, vestuário e utensílios. Em quase um terço dos lançamentos eles transacionaram dinheiro, representando a principal despesa debitada aos escravos, inclusive para o pagamento do seu escravista. Essas numerosas transações de valores substantivos dos escravos em pouco mais de um ano demonstram uma capacidade reiterada de manter negócios com a casa comercial. Embora apenas uma pequena parte deles alcançassem condições de acumular pecúlio, somente uma parcela ainda menor conseguiu sonhar com a liberdade.

\section{Palavras-Chave}

Escravidão. Comércio. Escravo. Negócios. Conta corrente.

\begin{abstract}
We explore the business of the slaves from the current accounts as clients of a commercial house in a hinterland economy at the end of the slave period, including debits and credits, money and merchandise. The slaves delivered corn and beans and bought a wide range of products, including food, clothing and utensils. Almost a third of the occurrences referred to money, representing the main expense debited to slaves, including the payment to the slave owner. These numerous amounts of substantive values in just over a year demonstrate a repeated ability to do business with a trading house. Although only a small part of them can afford to accumulate money, only an even smaller portion can obtain freedom.
\end{abstract}

- Agradeço a Paulo Lúcio a acolhida no Arquivo Público e Histórico de Tubarão (depois citado como APHT), bem como aos seus colegas. Versões iniciais desse trabalho foram apresentadas no $9^{\circ}$ Encontro de Escravidão e Liberdade no Brasil Meridional (maio de 2019) e no XIII Congresso Brasileiro de História Econômica (setembro de 2019). Agradeço aos participantes pelos comentários e sugestões e aos revisores da revista que melhoraram o artigo.

1 Professor - Universidade de São Paulo - Faculdade de Economia, Administração e Contabilidade de Ribeirão Preto - Endereço: Av. dos Bandeirantes, 3900 - Prédio C.1 Sala 62 - Campus Ribeirão Preto/SP - Brasil - CEP: 14048-900 - E-mail: rlmarcon@usp.br ORCiD: https://orcid.org/0000-0002-7002-621X.

Recebido: 05/11/2019. Aceite: 02/03/2020.

Editor Responsável: André Arruda Villela

(c) (i) (\$) Esta obra está licenciada com uma Licença Creative Commons Atribuição-Não Comercial 4.0 Internacional. 


\section{Keywords}

Slavery. Commerce. Slave. Business. Current account.

\section{JEL Classification}

N36. N56. N86.

\section{Introdução}

As roças dos escravos trabalhadas em dias livres marcaram a escravidão brasileira desde o período colonial, possibilitando uma economia autônoma para os escravos e a comercialização de excedentes da sua produção. ${ }^{1}$ As condições do direito de acesso à terra e ao trabalho variavam em cada local e período, podendo gerar conflitos principalmente no momento de sucessão das propriedades. De outro lado, alguns escravos de ganho conseguiam acumular rendimentos e obter a liberdade, como ocorrido durante a mineração no século XVIII e nos grandes centros urbanos, como Rio de Janeiro e Salvador. ${ }^{2}$ Posteriormente, as práticas de incentivos ao trabalho alargaram-se envolvendo mais cidades e o campo, até mesmo o pagamento por venda de mercadoria ou serviço extra. ${ }^{3}$ As atividades relacionadas ao abastecimento urbano permitiam uma teia de relações econômicas para os escravos, tanto a produção como a comercialização de alimentos e de serviços, como os de transportes e construção. ${ }^{4}$ De outro lado, os escravos consumiram produtos de variados tipos por meio de vendas de outros escravos, livres e até mesmo em lojas e tabernas, gerando algumas vezes débitos para serem saldados posteriormente. ${ }^{5}$

1 Ver, por exemplo, Dean (1977), Rio Claro, Cardoso (1987), Escravo ou Camponês? Schwartz (1988), Segredos Internos.

2 Ver Paiva (1995), Escravos e Libertos, Soares (1988), Escravos ao ganho, Karasch (2000), Vida dos Escravos, Frank (2004), Dutra's World, Valencia Villa (2011), Producción de la Liberdad.

3 Para Campinas, Regina Xavier anotou "Na própria contabilidade [para as décadas de 1870 e 1880/ RLM] das fazendas dos filhos de Camilo, vemos que alguns escravos vendiam produtos, como feijão e milho, para o administrador da fazenda. Embora não haja registros, é possível também que vendessem esses produtos nas vendas e nos mercados da cidade." (1996, Conquista da Liberdade, 81). Mais adiante refere-se a pagamentos diretamente aos escravos, como por trabalho em dia livre ou gratificação. Ver também Guimarães (2007), Experiências Econômicas, (2009) Terra de Preto, e Messias (2005), Fazenda Palmital.

4 Ver Graham (2013), Alimentar a Cidade, e, para os EUA, Hillard (2014), Masters, Slaves.

5 A Câmara de Campinas autorizou, desde 1820, escravos a estabelecer "vendas de porta aberta" e para quitanda, cf. Xavier (1996, Conquista da Liberdade, 78-79). 
$\mathrm{Na}$ busca pela alforria, os escravos mantinham créditos com seus proprietários desde a colônia. ${ }^{6}$ A posse de pecúlio e de bens tornou-se bastante regular. ${ }^{7}$ Posteriormente, a conta corrente em casas comerciais e depósitos nas caixas econômicas, como as da Corte e das províncias. ${ }^{8}$ A literatura historiográfica ressalta as possibilidades de negócios próprios dos escravos, mas há poucas informações mais detalhadas para uma economia direcionada ao mercado interno, principalmente os montantes e as mercadorias envolvidas. Pretendemos discutir os negócios dos escravos a partir dos lançamentos contábeis em suas contas correntes como clientes de uma casa comercial em Tubarão (Santa Catarina) ao final do período escravista, evolvendo débitos e créditos, dinheiro e mercadorias. Utilizamos outras fontes de forma complementar para entender as trajetórias dos escravistas e cativos, como inventários post mortem, testamentos, jornais e processos de alforrias.

Ao analisar o livro diário da contabilidade do comerciante João Machado Pacheco, uma primeira dificuldade para nós foi separar os negócios dos senhores e dos escravos, uma vez que tratavam com o mesmo comerciante e muitas vezes as transações eram efetuadas no mesmo dia. De forma ilustrativa, Walter Piazza (1975) relatou o cuidado dos mercadores em não confundir os débitos de escravos e senhores em Santa Catarina, calcado em anúncios publicados em jornais. ${ }^{9}$ Muitas vezes, o proprietário declarava não ser responsável por dívida ou produtos entregues a escravos. Um lojista do Desterro anunciou em 1856:

"previne a seus fregueses, e ao público em geral, que d'ora em diante não entregará fazenda a seus escravos sem que estes venham munidos de um bilhete assinado por seus respectivos senhores; isto para evitar dúvidas futuras, e continuadas fraudes que constantemente estão aparecendo." (O Argos da Província de Santa Catarina, 27 de maio de 1856, p. 4).

${ }_{6}$ Carla Almeida (2010) verificou em inventário de 1802 para a comarca do Rio das Mortes em Minas Gerais: "Chama a atenção uma das dívidas $(59$ \$700) que tinha por credor o escravo Bartolomeu de propriedade do casal, o que nos remete à existência de pequenos espaços de negociação e autonomia para os cativos dentro dessa sociedade tão rigidamente hierarquizada." (Ricos e Pobres, 85). Se o valor total das dívidas passivas era de $708 \$ 738$, o escravo detinha $8,4 \%$ do total das passivas.

7 Papali (2013) descreve a propriedade de casa e pés de café por escravos, em processos de ação de pecúlio e arrolamento (Senhores e seus Escravos, 8).

8 Ver, por exemplo, Saraiva \& Oliveira (2017), Caixa Econômica.

9 Piazza (1975), Escravo numa Economia. 
A exigência de ordem por escrito do senhor para entregar mercadorias ao escravo passou a ser comum em Desterro, segundo Piazza (1975). De outro lado, os proprietários declaravam nos jornais que não reconheceriam venda para os seus escravos ou suas dívidas. Assim, os cativos precisavam assumir a responsabilidade por seus débitos e os senhores não tentar se esquivar dos seus compromissos.

Apesar da atenção em evitar o jogo de transferência de débitos entre senhores e escravos, isto não impossibilitou aos cativos registrarem dívidas específicas na capital de Santa Catarina com relação aos comerciantes tanto os residentes no meio urbano como também no campo. Como mostra Clemente Gentil Penna (2005):

"Nos inventários de Carlos Ebel e Anacleto José Monteiro, ambos comerciantes falecidos em 1883 constam extensas listas das pessoas que ficaram a dever o pagamento de compras realizadas em suas lojas, entre elas alguns pretos e pretas como devedores, o que significa que eles tinham algum crédito na praça." (Escravidão, Liberdade, 90).

De outro lado, a liberta Eva mantinha-se como credora de suas clientes nos seus respectivos inventários (Escravidão, Liberdade, 108). A partir dos contratos de locação de serviços de ex-escravos, Henrique Espada Lima (2005) descreve a atuação desses personagens:

"o 'mercado' para os ex-escravos significava antes de tudo as ocupações não especializadas que envolviam o aluguel de suas forças como carregador ou outra ocupação braçal. São ocupações intermitentes, ligadas aos movimentos do porto, às obras públicas, a demandas localizadas de particulares. Incertos, descontínuos e mal pagos, constituem, entretanto, os trabalhos mais prováveis." (Sob o Domínio, 308).

A partir do seu trabalho e das relações sociais constituídas, eles assumiam posições ativas e passivas em relação a outras pessoas ou empresas. No caso do município de Tubarão, Paulo Henrique Lúcio (2006) relatou vários 
casos de ações de liberdade de escravos. ${ }^{10}$ Em alguns desses, os escravos informavam dispor de pecúlio para a compra da sua liberdade. Num desses casos, o escravo Venâncio de nação, em 1877, solicitava alforria nos seguintes termos:

"que possuindo um pecúlio de $200 \$ 000$ réis adquirido pelo seu trabalho e economias, deseja alforriar-se por aquela quantia por considerar que seja este o seu valor, não só pela sua idade avançada como também pelo seu estado valetudinário" (APHT, Ações de liberdade).

Nessa pesquisa de Lúcio, já foi verificado por meio das alforrias a existência de uma economia própria dos escravos em Tubarão. Embora Venâncio não seja objeto do nosso estudo, procuramos avançar na discussão dos negócios dos escravos com a casa comercial de João Machado Pacheco. A lei do ventre livre, de 1871, reconheceu e permitiu o pecúlio decorrente "de doações, legados e heranças, e com o que, por consentimento do senhor, obtiver do seu trabalho e economias". ${ }^{11}$ Assim, as leis do período favoreceram o registro do pecúlio e, consequentemente, dos negócios dos escravos com o seu senhor ou terceiros. A alforria por compra da liberdade e até mesmo o pecúlio alcançaram, mesmo na década de 1870, uma parte do contingente submetido à escravidão que conseguiu acumular um patrimônio. De outro lado, os negócios dos escravos como a compra e venda de bens e serviços não se registravam com tanta frequência, mas compreenderam um conjunto maior de cativos, pois nem todos conseguiram formar um pecúlio ou alcançar a tão sonhada liberdade.

Além desta introdução, dividimos o artigo em mais cinco partes. Na segunda, realizamos uma caracterização econômica da região de Tubarão e do seu contingente escravo a partir da estimativa da população do meado do século XIX e do censo de 1872. Na seguinte, discutimos o perfil de atividades do proprietário da casa de negócio e dos escravagistas que possuíam os cativos que transacionaram com a loja, calcados principalmente em inventários post-morten e testamento. Mais adiante, analisamos os negócios dos escravos com a casa por meio do livro diário de 1875 a $1876 .^{12}$

${ }^{10}$ Lúcio (2006), Escravidão em Santa Catarina.

${ }^{11}$ Lei 2.040 de 28 de setembro de 1871.

${ }^{12} \mathrm{O}$ livro diário de João Machado Pacheco encontra-se depositado no Arquivo Público e Histórico de Tubarão (APHT). Apesar de recentemente encadernado, esse livro está incompleto, faltando algu- 
Nele podemos verificar os valores creditados e debitados dos cativos, compreendendo as compras e vendas de mercadorias e as operações em conta corrente. Em seguida, destacamos os escravos que negociaram com a loja e conseguiram a liberdade, algumas vezes com o auxílio do Fundo de Emancipação. ${ }^{13}$ As considerações finais encerram o trabalho.

\section{Tubarão - Santa Catarina}

O Sul de Santa Catarina desenvolveu-se a partir do estabelecimento de Laguna ao final do século XVII, objetivando facilitar a expansão meridional do território e do comércio. ${ }^{14} \mathrm{~A}$ imigração açoriana e a busca pelo gado favoreceram a ocupação da região de Laguna no século XVIII. A economia direcionou-se para o mercado interno, principalmente por meio da pecuária e da agricultura de abastecimento da capitania e, posteriormente, até mesmo do Rio de Janeiro. Havia um caminho de tropas ao longo do Rio Tubarão para alcançar o planalto de Lages, que constituía eixo importante do comércio de gado do Rio Grande para o Sudeste da colônia. ${ }^{15}$ As primeiras sesmarias foram concedidas no rio Tubarão ao final do século XVIII. Posteriormente, o distrito de Tubarão foi criado em 1836 e elevado à condição de vila em 1870 .

O viajante Robert Avé-Lallemant esteve na região de Laguna e Tubarão em 1858. Ele observou uma economia muito semelhante à de outras partes do litoral catarinense, calcada na oferta de alimentos para a principal praça comercial do país:

"Farinha de mandioca, diferentes espécies de feijão e milho são exportadas de Laguna em considerável quantidade e vendidas a bons preços no Rio de Janeiro." (Viagens, 36).

mas dezenas de páginas. O período de anotação compreendeu de junho de 1875 a agosto de 1876, havendo lacunas principalmente dos meses de janeiro e fevereiro de 1876.

${ }^{13}$ O Fundo de Emancipação criado na lei do Ventre Livre recebeu recursos para a libertação de cativos, por meio principalmente de taxa e impostos sobre a propriedade escrava. Os montantes arrecadados distribuíam-se pelos municípios e as juntas municipais de classificação efetuavam os processos de liberdade. Ver Dauwe (2004), Libertação Gradual.

14 A freguesia foi criada em 1697 e a vila em 1714.

15 Ver Mapa 1 no Anexo. 
Com relação a Tubarão, o viajante alemão notou a pujança da agricultura direcionada para o mercado interno:

"bonitas plantações, algumas das quais ornadas com belas casas. Por toda parte brilham milhares de laranjas, tanto que o nobre fruto é dado como forragem aos porcos. Em toda parte se vêem plantações de mandioca e milharais." (Viagens, 40).

De acordo com os informes levantados por Laura Hübener (1981), Laguna respondia por cerca de um quinto das exportações dos principais municípios catarinenses em 1849-50. Em termos das exportações de farinha, Laguna perfez pouco menos de um terço do total (31,2\%), somando 157 mil alqueires. Com relação ao milho, o município lagunense era o principal exportador, atingindo mais da metade $(61,6 \%)$. O volume exportado de milho chegou a 43 mil alqueires. O principal destino da exportação de Laguna foi para portos da própria província $(70,0 \%)$, seguido pelo Rio de Janeiro $(24,8 \%)$ e Santos $(3,7 \%) .{ }^{16} \mathrm{O}$ principal porto de comércio com Laguna consistiu na capital da província.

Posteriormente, as mesmas mercadorias continuavam a ser enviadas para fora da região pelo porto de Laguna na foz do Rio Tubarão, principalmente farinha de mandioca, milho, feijão e aguardente. ${ }^{17} \mathrm{~A}$ farinha, madeiras e cereais também eram os principais de exportação por Santa Catarina, desde o meado do século XIX. ${ }^{18}$ Segundo Hübener (1981), os volumes exportados em alqueires de farinha de mandioca por Santa Catarina responderam, entre $1869-1872$, por $78,0 \%$ dos principais alimentos, seguindo pelo milho $18,5 \%$, fava $2,0 \%$ e feijão e goma por $0,7 \%$ cada. ${ }^{19} \mathrm{O}$ porto da Laguna auxiliava de modo expressivo nesses montantes, principalmente por meio do milho e da farinha.

\footnotetext{
${ }^{16}$ Hübener (1981), Comércio da Cidade, 28-31.

17 de milho em 1878 e posteriormente de feijão (cf. Retrospecto Comercial do Jornal do Comércio de 1875, 1878 e 1883, www.memoria.bn.br visitado em 20 de maio de 2019). O jornal lagunense apresenta os preços correntes das seguintes mercadorias na cidade e nos sítios, dos quais apresentamos apenas os nos sítios que deveria corresponder melhor ao interior da região: farinha comum $(2 \$ 240)$ e fina $(3 \$ 000)$, feijão $(4000)$, fava $(2 \$ 500)$, milho graúdo $(2 \$ 240)$ e miúdo $(2 \$ 500)$ e couros $(A$ Verdade, 20 de julho de 1879, p. 3).

18 Brasil, Documentos Estatísticos, 20.

${ }^{19}$ Hübener (1981), Comércio da Cidade, 83.
} 
O movimento imigratório de europeus para a região cresceu a partir de 1877 destinado a Azambuja e depois a outras colônias na região Sul da província. Ademais, o desenvolvimento da exploração do carvão e início da construção da ferrovia em 1880 dinamizaram de forma extraordinária a região, levando a um rush demográfico e econômico. ${ }^{20}$ A comunicação com o planalto de Lages possibilitava o abastecimento de ampla região de pecuária. $^{21}$

No Mapa aproximado da população da província de 1855, Tubarão detinha 632 cativos de pouco mais de seis mil habitantes, representando pouco mais de um décimo do conjunto dos moradores (10,3\%). A grande maioria dos escravos era de homens, perfazendo pouco menos de dois terços do total (62,2\%). ${ }^{22}$ Poucos anos depois, a população escravizada do município cresceu para 1.019 escravos no recenseamento de 1872, porém a proporção com relação ao total dos moradores reduziu-se a $8,0 \% .{ }^{23}$ Dos cativos, cerca de pouco mais da metade era de mulheres $(50,3 \%)$, revelando maior equilíbrio numérico entre os sexos possivelmente em razão do término do tráfico atlântico. ${ }^{24}$

Dos escravos do censo, 114 nasceram na África, representando 11,2\% do total. Ainda havia 13 africanos livres, dos quais três viúvos e seis casados. Dos brasileiros, a quase totalidade nasceu em Santa Catarina, mas havia 22 do Rio Grande do Sul e um de São Paulo. As principais profissões foram de lavrador para 583 pessoas, principalmente homens, e de serviço doméstico e costureiras para 223 indivíduos, mormente mulheres.

Das pouco mais de onze mil pessoas livres no censo de 1872, as profissões anotadas consistiram, principalmente, em lavradores $(68,6 \%) .{ }^{25}$ Os comerciantes e caixeiros compreendiam um reduzido número dos habitantes, alcançando apenas 58 pessoas. No Almanaque Laemmert de 1885, verificamos a presença de 23 negociantes na vila e mais 80 fora do centro do município. João Machado Pacheco, proprietário da casa comercial em

${ }^{20}$ Ver Goularti Filho (2002), Formação Econômica, 69-70. Ver Mapa 2 no anexo.

${ }^{21}$ Havia uma demanda da modernização da estrada do município de Tubarão para Lages, facilitando a troca de gêneros de primeira necessidade (Silva, 1875, Falla Dirigida, 90).

${ }^{22}$ Ver Coutinho (1855), Relatório do Presidente, Mapa SN). Léonce Aubé apresentou, para 1856, a população de Tubarão como sendo de 4.124 habitantes, dos quais 823 cativos (Apud Piazza, 1975, Escravo numa Economia, 24). A proporção de escravos na população chegou a um quinto do total.

${ }^{23} \mathrm{O}$ município de Tubarão compreendia a freguesia de Araranguá.

${ }^{24}$ Havia apenas cinco escravos declarados como casados e dois viúvos. Esses últimos eram africanos.

${ }^{25}$ Pouco mais de cinco mil pessoas não tiveram profissão anotada, os quais não eram apenas crianças. 
estudo neste artigo, era apenas um desses negociantes, revelando a existência de um conjunto mais amplo de relações mercantis naquele momento. ${ }^{26}$

O porto de Laguna constituía a porta de entrada e saída para a região do Rio Tubarão. Na década de 1870, o sistema de transporte avançou por meio da introdução de vapores, que facilitavam a movimentação de pessoas e cargas. O primeiro "vaporzinho" Itapirobá foi da Companhia Catarinense, a fim de rebocar navios a vela e fazer duas viagens mensais para o Desterro (Jornal do Comércio de 13 de junho de 1870, p. 1). ${ }^{27}$ Nessa reportagem, o porto foi descrito como "já é considerável o movimento de barcos de cabotagem" (Jornal do Comércio de 13 de junho de 1870, p. 1). A companhia conseguiu uma subvenção anual de 12 contos anuais por parte do governo provincial com duração de 15 anos, de acordo com a lei de 4 de maio de 1869 (Jornal do Comércio de 30 de agosto de 1870, p. 3-4). ${ }^{28}$ Poucos anos mais tarde, a própria Assembleia suspendeu a subvenção em maio de 1872 (Jornal do Comércio de 16 de setembro de 1873, p. 2).

Na época, o jornal $A$ Verdade sintetizou o movimento do porto de Laguna (em edição de 5 de outubro de 1879, p. 3). No decênio de 1868 a 1878, verificamos a movimentação de 1.705 embarcações, sendo 956 para fora da província. Os principais produtos transportados foram farinha de mandioca (40.132 toneladas), milho (36.158), feijão (3.456), favas (3.294) e carne seca (1.102). Desses, enviaram para fora da província milho (33.079 toneladas), farinha (27.408), favas (2.751) e feijão (2.713), mas não carne seca. Ainda havia a saída de aguardente, totalizando 331 mil litros, dos quais 294 mil para fora da província. Por fim, ainda notamos o embarque de couros de boi (111 mil) e peixes secos (69 mil). Assim, podemos verificar os principais produtos negociados para fora da região.

Poucos anos mais tarde, houve a tentativa de avanço da navegação a vapor no Rio Tubarão e seus afluentes ocorreu por intermédio de Francisco Fernandes Martins em 1879. Ele requereu ao governador o privilégio de passageiros e chatas com gêneros. Na solicitação, ele salientava a riqueza do comércio:

"mantem ele relações em alto pé, não só com a praça desta cidade [Laguna/RLM], como também com a do Rio de Janeiro, e o meio de transporte de que

${ }^{26}$ Ver Sauer (1885), Almanak Administrativo, 1346-48.

27 Ver reprodução da propaganda na Figura 1 do anexo.

${ }^{28} \mathrm{O}$ governo ainda teria direito de conduzir gratuitamente as malas do correio oficial, pessoas que o governo determinasse e cargas que não excedesse metade da lotação do vapor. 
dispõe para condução de cereais que em quantidade enorme exporta, e de gêneros para seu mercado, que, em não inferior quantidade, também importa, são unicamente pequenos iates e lanchas que, além de morosamente fazerem o serviço, nem sempre podem vencer as inumeras dificuldades que lhes aparecem, com o que sofre deveras, não só o comércio de Tubarão, como o de exportação da Laguna." (A Verdade, 17 de agosto de 1879, p. 2).

Ainda, argumentou da existência da Colônia em Azambuja e da possibilidade de o vapor ajudar a rebocar os veleiros na saída do porto de Laguna para o Rio de Janeiro. Assim, o jornal apoiou a iniciativa que poderia desenvolver a economia de toda a região.

O Barão de Laguna discursou no Senado afirmando que o porto merecia maior apoio em função da relevância da região para a rede de abastecimento da Corte:

"O município da Laguna é um dos grandes concorrentes ao comércio da capital do Império com gêneros alimentícios carregados ou exportados em cerca de 20 navios, mensalmente para o porto do Rio de Janeiro." (A Verdade, 23 de novembro de 1879, p. 3).

Por fim, no Almanaque Laemmert de 1885, descreveu-se que Tubarão "Cultiva milho, mandioca, feijão e fava, e em pequena escala cana, café e fumo". ${ }^{29}$ A principal atividade econômica do município de Tubarão consistiu, portanto, na agricultura. Desse modo, a região apresentava dinamismo econômico e demográfico no período, compreendendo a população escrava.

${ }^{29}$ Sauer (1885), Almanak Administrativo, 1343. 


\section{Escravagistas}

O negociante João Machado Pacheco mantinha casa de negócio pelo menos desde a década de 1860. Em 1859, ele viajou ao Rio de Janeiro num paquete a vapor da linha de Montevideo. ${ }^{30} \mathrm{Em} \mathrm{1861}$, ele requereu ao governo da província a compra de terras em Tubarão. ${ }^{31}$ Ele casou-se três vezes, sendo inventariante em todos os inventários. A primeira esposa, Cecília Maria do Nascimento ou Antonia de Jesus, era filha do comerciante José Gonçalves de Faria. O próprio negociante já emprestava regularmente a escravos. ${ }^{32}$ Assim, a prática de vender, comprar e emprestar a escravos revelou-se difundida no município.

No inventário do primeiro cônjuge de Pacheco, o balanço da casa de negócio alcançou, em 1866, quase quatro contos de réis em mercadorias, compreendendo principalmente tecidos, ferragens e louça. ${ }^{33}$ De outro, a casa mantinha cerca de 75 mil réis em equipamentos (como balança, pesos e lampião), 80 mil réis em animais (uma junta de bois e uma besta) e 106\$200 réis em dinheiro de cobre, prata e principalmente papel. O negociante possuía um escravo de nome João de 36 anos e Maria preta de 40 anos. Os bens de raiz somaram 6,6 contos de réis. As dívidas ativas da casa abrangeram 187 pessoas e um montante de 6,37 contos de réis. Assim, o ativo total somou pouco mais de dez contos de réis, mas as dívidas passivas totalizaram quase o mesmo valor. Dos cinco credores, quatro consistiam em companhias do Rio de Janeiro, que deveriam fornecer mercadorias a casa e apenas uma pessoa física. Destacava-se a dívida do valor de pouco 5,18 contos de réis de Pacheco \& Cia, fornecendo desde pelo menos 1864 principalmente fazendas a prazo de um ano. ${ }^{34}$ Entre os devedores da casa de negócio, já havia Miguel escravo de Francisco Rabello no valor de 9\$780 réis, representando apenas $0,2 \%$ do total das dívidas a receber pela casa.

${ }^{30}$ Correio Mercantil, 2 de outubro de 1859 , p. 4.

${ }^{31}$ O Correio Oficial, 29 de março de 1861, p. 3; e 6 de junho de 1861, p. 3.

$32 \mathrm{O}$ primeiro sogro faleceu em 1872, deixando herança aos netos, sob tutela do pai João Machado Pacheco. Entre os bens do sogro havia quase quinze contos de réis em mercadorias. A prática de financiar os escravos clientes já era rotina nos negócios do sogro, que declararam existir a dívida ativa de "Merciana escrava do Paracha?" (1\$920), "Miguel escravo do Rebelo" (15\$400), "a escrava do falecido Coelho?" (2\$36), "escravo do Manoel Nunes" (20\$600), "Diogo escravo do Custodio" (9720), "Francisco escravo do João Roiz" (3\$34), "Salvador escrava do Madr.a?" (2\$400) e "Francisco escravo de Manoel Sebastião" (82\$860). Este último também foi cliente de João Machado Pacheco em 1875-76. Ainda havia os créditos a seu favor de "Luiza, crioula que está em casa do José Mendes" (3\$50), "Thomazia criola" (3420) e "Graciana crioula" (35\$460). APHT, Pasta 17.

33 APHT, Pasta 37.

${ }^{34}$ Cassão \& Paranhos era credor de 2,47 contos de réis e Francisco José Teixeira Bastos \& Cia de 1,60 contos em conta corrente. Por fim, Azevedo Júnior \& Cia do Rio de Janeiro embarcou 0,60 contos de réis em gêneros molhados por prazo de seis meses. 
João Machado Pacheco desposou, em sequência, duas filhas de Custódio Pinto de Sampaio, que era seu cliente e devia $74 \$ 680$ réis em 1866. A primeira foi Maria Emília de Sampaio, falecida em 1877, com a qual teve os filhos José e Joana. Por fim, ele casou-se em 1878, com Lucinda Emília de Sampaio, e tiveram a filha Mariana; porém, a esposa faleceu em $1882 .{ }^{35}$ No inventário da primeira filha de Custódio em 1877, as mercadorias da casa compreenderam fazendas, ferragens, miudezas, louças, molhados, chapéus, drogas e utensílios. ${ }^{36} \mathrm{O}$ balanço das mercadorias somou quase sete contos de réis, superando amplamente os valores do inventário anterior. Os bens de raiz totalizaram um valor muito superior ao inventário anterior: 17 contos de réis. As dívidas ativas chegaram a pouco mais de 28 contos e o monte mor a quase 54 contos. Isto demonstra o acúmulo de riqueza pelo negociante em cerca de uma década, pois recebeu a meação do inventário da primeira esposa pouco mais de 10 contos de réis. Talvez ele tenha assumido parte da clientela do antigo sogro, que faleceu em 1872, e a tutela dos bens dos filhos do primeiro casamento, facilitando sua acumulação. ${ }^{37}$

No inventário da primeira filha de Custódio, entre os devedores da casa encontravam-se seis escravos num débito total de pouco mais de $150 \mathrm{mil}$ réis. Entre eles, havia Roque escravo de Sampaio e de outros escravagistas da região. Os cativos eram Adão, Seforiano, Francisco e Antonio. Por fim, existia a dívida do cativo Braz de um proprietário de Lages, que também era devedor da casa. Dessas dívidas dos escravos, apenas uma se classificou como incobrável, no valor de $4 \$ 800$ réis. A proporção das dívidas dos escravos em relação ao total das dívidas da loja em 1877 foi de $0,7 \%$, com relação às cobráveis, e apenas $0,1 \%$ das incobráveis. Novamente, as dívidas dos escravos representavam pequenina parcela do total da casa. Apesar da proporção reduzida, ainda assim mereciam atenção do dono da casa. De outro lado, para os escravos eram valores substantivos que permitiram a aquisição de produtos e acesso a dinheiro para pagamentos, como veremos adiante.

${ }^{35}$ A Reforma, 11 de abril de 1878, 2. No inventário do sogro em 1889, ele foi descrito como negociante. A esposa já tinha falecido, deixando sob sua tutela a filha Mariana de 9 anos e José 17 anos. A outra filha já se encontrava casada.

${ }^{36}$ APHT, Pasta 36.

${ }^{37}$ Ele dispôs-se no inventário do primeiro sogro a ficar com todas as mercadorias. 
Cinco anos mais tarde, no inventário da segunda filha de Custódio, as mercadorias atingiram um valor de 2,5 contos de réis, as dívidas ativas a 18,6 contos e o monte mor a 32,6 contos, muito inferiores aos do levantamento anterior. ${ }^{38}$ Ele diminuiu a representação dos bens de raiz no patrimônio $(29,4 \%)$ e elevou a de dívidas ativas $(57,1 \%)$. Ele ainda detinha os escravos: Maria, Martha e Damazia. Apontando para uma pequena acumulação de riqueza pessoal, já que no inventário da segunda esposa recebeu quase vinte e sete contos de réis de sua meação. Com relação aos créditos referentes a escravos, notamos a presença de Francisco de João Rebello (21\$050), Joaquim de José Mendes (32\$560), José de José Motta (4260), Procecio de João Pinto de Arruda (13\$020) e Manuel de Januário Pinto (11\$630). ${ }^{39}$ Essas quantias perfizeram 0,5\% das dívidas ativas no inventário. Em 1885, João Machado Pacheco foi descrito no Almanaque como capitalista, negociante e fazendeiro. ${ }^{40}$ Quando do inventário da sogra em 1889, ele foi descrito como negociante em Pedras Grandes no município de Tubarão. ${ }^{41}$

O primeiro registro do português Custódio Pinto de Sampaio foi a saída do Rio de Janeiro em 1838 para Laguna como passageiro de uma sumaca. ${ }^{42}$ Ele era agricultor em Tubarão, comprando terras na região e pedindo a demarcação e confirmação ao governo no início da década de 1870 . No inventário da sua mulher em 1889, já com mais de setenta anos de idade, ele declarou possuir animais (como juntas de bois, vacas e novilhas), dois arados, debulhador de milho, carro, canoa, uma casa que serve de paiol, caixão para depositar farinha, máquina de costura e várias terras às margens do rio Tubarão. Havia ainda roças de milho por colher avaliadas em $600 \$ 000$ e outra de feijão também por colher por $100 \$ 000$.

Declarou entre os bens o arrendamento de terras de João Paes de Faria, cujo contrato é a pagar no mês de agosto vindouro a quantia de $200 \$ 000$. Outro contrato com Antonio de tal de arrendamento a pagar em agosto a quantia de 50\$000. Por fim, outros arrendamentos em mão de José Motta no valor de 200\$000, Assis Vicente de 150\$000, Jose Aroemo de $100 \$ 000$, Rodolfo Krause $150 \$ 000 .{ }^{43}$ Assim, nesse momento ele detinha 5 contratos de arrendamento com diferentes pessoas. As roças por colher foram avaliadas em $700 \$ 000$ réis. O monte mor chegou a quase oitenta

\footnotetext{
38 APHT, Pasta 36.

${ }^{39}$ Ainda havia a dívida de Miguel, ex-escravo de Diziderio da Silva Cascaes, com 18\$800, e a de Patrícia, parda de $5 \$ 300$.

${ }^{40}$ Sauer (1885), Almanak Administrativo, 1344 e 1346.

${ }^{41}$ APHT, Pasta 20.

42 Diário do Rio de Janeiro, 11 de julho de 1838, p. 4.

${ }^{43}$ Este último detinha uma serraria na propriedade.
} 
contos de réis, dos quais os bens de raiz representaram 92,7\% do total. A idade avançada pode ser uma explicação para a escolha. As dívidas ativas e passivas eram pouco representativas no seu patrimônio em comparação aos inventários de comerciantes como do seu genro, atingindo 4,4 contos a primeira e 5,9 a segunda.

Outro proprietário de escravo que negociou com a casa de João Machado Pacheco foi José Ignácio de Faria. Ele possuía terras e um escravo segundo seu testamento e inventário em 1884, quando declarou não saber ler nem escrever. ${ }^{44}$ Ele era natural de Laguna e viúvo naquele momento.

Ainda houve mais dois proprietários de cativos que negociaram com a loja. Primeiro, João Rabello Flores recebeu no inventário do seu pai o escravo Candido, de idade 22 anos, avaliado por $800 \$ 000$ em 1872. Por outro lado, José Mendes Ouriques detinha 5 escravos na matrícula em 1872, sendo 3 homens roceiros, uma mulher cozinheira e uma criança de 2 anos, filha dela. No processo de arbitramento do seu escravo, Ouriques informou não saber ler nem escrever. ${ }^{45}$ Posteriormente, ele foi descrito como lavrador em Tubarão no Almanaque Laemmert de $1885 .{ }^{46}$ Conclui-se, com efeito, que a atividade agrícola consistia na principal atividade dos escravistas e, possivelmente, na ocupação mais comum dos escravos.

\section{Escravos}

No livro diário da casa de negócio de João Machado Pacheco, verificamos a presença de 16 escravos, dos quais apenas uma era mulher. ${ }^{47}$ Oito desses cativos eram de propriedade de Custódio Pinto de Sampaio, que foi o segundo sogro do comerciante. Os dezesseis realizaram 172 transações anotadas no livro contábil em pouco mais de um ano, envolvendo débitos e créditos totais de quase dois contos de réis. Se, por um lado, uma dúzia de escravos detiveram créditos a seu favor na casa, perfazendo média de 165 mil réis por pessoa, por outro, todos assumiram débitos com a loja, atingindo valor médio de 113 mil réis por indivíduo. Por fim, o saldo das

\footnotetext{
${ }^{44}$ APHT, Pasta 20.

45 Arbitramento - Juízo Municipal do Tubarão (1882). APHT, Pasta 39.

46 Sauer, Almanak Administrativo, 1346.

47 Nenhum deles encontra-se na relação de escravos devedores no inventário da esposa de 1877.
} 
operações dos escravos alcançou dívida total a receber da loja de $178 \mathrm{mil}$ réis, como pode ser visto na Tabela 1 abaixo. Destarte, eles consistiram em credores líquidos da casa comercial naquele momento que dispomos dos registros das suas transações, revelando a possibilidade de formarem pecúlio.

Dos lançamentos realizados, cerca de um terço referia-se a operações com dinheiro a crédito ou principalmente a débito. ${ }^{48} \mathrm{~A}$ casa fornecia recorrentemente dinheiro aos escravos, como "que pediu", "entregou", "suprido" e "que lhe dou por saldo". Algumas poucas vezes há a destinação, como para sabão, carne ou para um queijo. Outras vezes para ser entregue a um terceiro por sua ordem, não apenas livres, mas também cativos. Como no caso de Miguel mulato, que assumiu um débito de $8 \$ 000$, a fim de a casa fornecer o dinheiro a Miguel preto, não obstante serem ambos de propriedade do mesmo escravagista.

48 Já para o período pós-abolição, os fazendeiros utilizavam-se regularmente de cadernetas para anotar diversas transações dos seus ex-escravos, nacionais e imigrantes. Luiz Fernando Saraiva e Jonis Freire (2018) - Pertence a Firmina, 301-09 - observaram um grande volume de transações registradas entre 1888 e 1897 na Zona da Mata Mineira, somando quase onze mil débitos e 67 contos de réis para 232 pessoas. Desses, o empréstimo de dinheiro ou adiantamento constituía a principal despesa dos fazendeiros com seus trabalhadores, chegando a um terço dos valores lançados $(33,6 \%)$. O valor médio por trabalhador foi de 291 mil réis, superando em muito a média dos débitos da casa de João Machado Pacheco. Isto decorreu do período posterior e da inflação acumulada e da maior prosperidade da economia cafeeira. 
Tabela 1 - Lançamentos e saldo dos escravos na Casa de Negócio

\begin{tabular}{lrrrrl}
\hline Escravo & $\mathbf{N}^{\circ}$ & Débitos & Créditos & \multicolumn{1}{c}{ Saldo } & Proprietário \\
\hline Agostinho & 2 & $128 \$ 000$ & $-81 \$ 250$ & $46 \$ 750$ & Custódio Pinto de Sampaio \\
Al $($ r)cencio & 25 & $677 \$ 269$ & $-804 \$ 260$ & $-126 \$ 991$ & Custódio Pinto de Sampaio \\
Bento & 5 & $72 \$ 240$ & $-215 \$ 320$ & $-143 \$ 080$ & Custódio Pinto de Sampaio \\
Brás & 3 & $26 \$ 160$ & 0 & $26 \$ 160$ & Manoel Joaquim \\
Candido & 12 & $115 \$ 060$ & $-16 \$ 800$ & $98 \$ 260$ & João Rebello Flores \\
Domingos & 15 & $403 \$ 980$ & $-491 \$ 000$ & $-87 \$ 020$ & Custódio Pinto de Sampaio \\
Estevão & 2 & $6 \$ 240$ & 0 & $6 \$ 240$ & Custódio Pinto de Sampaio \\
Felicidade & 5 & $10 \$ 980$ & $-6 \$ 700$ & $4 \$ 280$ & José lgnácio de Faria \\
Francisco & 2 & $28 \$ 880$ & $-83 \$ 000$ & $-54 \$ 120$ & João Rebello Flores \\
Francisco & 4 & $10 \$ 600$ & 0 & $10 \$ 600$ & Manoel Sebastião \\
Joaquim de José & 13 & $51 \$ 160$ & $-38 \$ 400$ & $12 \$ 760$ & José Mendes (Ouriques) \\
Joaquim & 2 & 920 & -720 & 200 & Bernardino ou Bernardo \\
Miguel Mulato ** & 45 & $123 \$ 850$ & $-100 \$ 000$ & $23 \$ 850$ & Custódio Pinto de Sampaio \\
Miguel Preto ** & 23 & $118 \$ 940$ & $-139 \$ 260$ & $20 \$ 320$ & Custódio Pinto de Sampaio \\
Pedro & 2 & $2 \$ 500$ & $-1 \$ 480$ & $1 \$ 020$ & Bernardino ou Bernardo \\
Vicente * & 10 & $22 \$ 340$ & 0 & $22 \$ 340$ & Custódio Pinto de Sampaio \\
Total * & 171 & $1: 800 \$ 119$ & $-1: 978 \$ 190$ & $-178 \$ 071$ & \\
\hline
\end{tabular}

Fonte: Livro Diário de João Machado Pacheco. APHT.

Obs: Saldo é a favor da Casa. O total inclui o débito de Miguel preto ou mulato.

* há um lançamento sem valor, que não foi computado na tabela.

** há um lançamento de débito de Miguel, que não sabemos se mulato ou preto, no valor de $1 \$ 000$.

Outra ilustração de negócios com dinheiro foi a transação de Agostinho que tomou, em julho de 1876 , um débito de $128 \$ 000$ réis com a casa de negócios no mesmo dia que o seu proprietário recebeu um crédito desse valor. Como o escravo detinha um saldo de sua conta de apenas 28\$000, João Machado Pacheco financiou em $100 \$ 000$ o escravo Agostinho do seu sogro. O escravo assumiu dívida de quantia expressiva para pagamento ao seu senhor. Infelizmente, não sabemos o motivo. De toda a sorte, pouco mais de uma semana depois o referido escravo entregou 32,5 alqueires de feijão, perfazendo $81 \$ 250$ réis, abatendo grande parte da dívida. 
Custódio Pinto de Sampaio recebia regularmente dinheiro dos seus escravos, por intermédio do comerciante. Ele anotou também dois débitos ao escravo Alcenio, o primeiro em julho de 1875, e o segundo em março de 1876 , no valor de $125 \$ 960$ cada um, por conta de dinheiro "por sua ordem" fornecido ao seu senhor. O escravo ainda sacou 334\$469 em "dinheiro que lhe dou por saldo". Ele foi o escravo que transacionou as maiores quantias, respondendo por cerca de quatro décimos do total, respondendo por $37,6 \%$ dos débitos e $40,7 \%$ dos créditos. Nesse caso, apesar das quantias expressivas negociadas em dinheiro, o escravo conseguiu honrar seus compromissos. Por fim, Bento assumiu débito com a casa de $72 \$ 000$ réis em novembro de 1875, a fim de ela fornecer dinheiro para seu escravista. Contudo, nesse mesmo dia houve a entrega de milho e outros acertos do escravo e o comerciante possivelmente para encerrar a conta, até mesmo um lançamento de perdão de dívida no valor de $4 \$ 200$ réis em favor de Bento. Por fim, outros escravagistas também recebiam dinheiro dos seus escravos por meio da loja. Ainda havia mais um caso do escravo Francisco de João Rebello Flores, aceitando um débito para a casa dar $28 \$ 800$ réis em dinheiro "ao seu senhor".

Todas as 58 operações em dinheiro representaram apenas um terço dos 172 lançamentos, porém, as quantias negociadas foram muito mais expressivas em relação ao valor total transacionado. Para os débitos, os montantes de dinheiro envolvidos nessas transações somaram 1:575\$029 réis, representando $87,5 \%$ do total desses lançamentos. ${ }^{49}$ Dinheiro constituía a grande maioria dos valores debitados dos escravos e não consumo de mercadorias ou serviços. De outro lado, houve apenas dez lançamentos a crédito, que totalizaram 845\$120 réis. Grande parcela desse último valor decorria de depósito em 1875, de 370 mil réis de Domingos, que foi sacado no mesmo dia. O segundo maior montante ocorreu por meio de restituição de outra conta, sendo o pouco restante entregue em dinheiro por saldo e uma doação do comerciante, já mencionada acima. Desse modo, o total de créditos em dinheiro representou tão-somente $42,7 \%$ do total. Dinheiro não foi a principal forma de gerar crédito aos escravos.

Como então os escravos pagavam seus débitos em mercadorias e principalmente em dinheiro? A grande maioria dos créditos a favor dos escravos ocorreu pelo fornecimento principalmente de milho em oito vezes por diferentes cativos, totalizando $986 \$ 820$ réis ou quase trinta mil litros do

${ }^{49}$ Tal porcentual mostrou-se muito superior ao verificado por Saraiva \& Freire (2018), Pertence a Firmina, 309. 
produto. Além desse bem mais relevante nos negócios, havia ainda três operações com feijão, somando $175 \$ 770$ réis ou pouco mais de dois mil litros do produto. No total dos dois alimentos, os cativos ganharam o crédito de pouco mais de um conto de réis por conta do fornecimento desses alimentos, representando 57,3\% do total creditado aos escravos. Esse meio consistiu na principal forma de honrarem seus compromissos com a casa. De outro lado, os quatro débitos de cereais deveram-se à compra de farinha em três oportunidades (somando 140 litros) e ao pequeno desconto num fornecimento de milho. Destarte, a produção de alimentos foi a principal forma de obtenção de recursos por parte dos escravos em poucas, mas vultosas, operações, principalmente por meio da venda de milho.

Podemos pensar que os preços pagos aos produtos dos escravos fossem sistematicamente menores do que os dos senhores ou livres em geral. De outro lado, o mercador poderia vender ou comprar a preços distintos em detrimento dos escravos que teriam piores condições de comercialização dos seus bens. Para avaliar essa possibilidade, lançamos mão das anotações no mesmo dia e produto por parte dos escravos e de seus proprietários. Assim, podemos comparar de forma mais efetiva os preços de comercialização deles.

No referente aos preços de compra de produtos, verificamos que em setembro de 1875 , a casa de negócio comprou 3.440 litros de milho de Francisco do proprietário João Rebello Flores, por cerca de 24 réis por litro. O seu escravista vendeu 11 mil litros de milho por 26 réis cada um e 800 litros por 25. De outro lado, o escravo Joaquim comercializou com a loja 1.200 litros de milho em outubro de 1875 , por 32 réis cada um. O seu proprietário José Mendes vendeu 8.640 litros de milho também por 32 réis. Por fim, no dia 10 de julho de 1875, dois escravos do sogro venderam cerca de 800 litros de feijão por cerca de 86 réis cada, bem como duas pessoas livres (Manoel José Machado P. e Vicente Nazario de Faria) pouco mais de 540 litros por cerca de 69 réis cada. Nesse caso, o feijão dos escravos foi em maior volume e mais valioso do que o dos livres. Desse modo, não verificamos distinções sistemáticas entre os preços do milho e do feijão praticados entre os escravos e livres que pudessem ser atribuídos a sua condição. 
Para a aquisição de bens pelos escravos também não nos pareceu haver distinção de preços. Num caso conseguimos ter proximidade da data dos lançamentos de venda do produto para o escravo e o seu escravagista. Como foi o caso de Alcencio, que comprou 15 quilogramas de carne no dia 11 de julho de 1875 , por $6 \$ 000$. O seu proprietário comprou idêntica quantidade pelo mesmo valor no dia 19 de julho. Noutro caso, o escravo Candido comprou, em 6 de agosto de 1875, 900 gramas de café por 720 réis e, no mesmo dia, a loja vendeu para um livre 3,6 quilos de café por $2 \$ 880$ réis, idêntico ao preço de comercialização. Desse modo, também para as vendas de mercadorias não verificamos diferenças de preços entre livres e escravos.

No conjunto, houve grande número de lançamentos de aquisições de produtos não alimentares, atingindo 48 ocorrências para vestuário por parte de dez cativos e 30 para utensílios por nove escravos. Entre as mercadorias adquiridas pelos escravos encontravam-se diferentes tipos de tecidos, botina, chapéus, faca, pólvora, xícaras, pratos etc. Todavia, a soma desses débitos totalizou apenas $176 \$ 830$ réis. Um exemplo pode ser visto nas compras de Cândido, que adquiriu um lenço por 480 réis, um par de tamanco por 560 réis, seis metros de riscado por $4 \$ 500$ réis, duas peças de pano por 7 mil réis e um xale de lã e algodão por 8 mil réis. Os tecidos foram os objetos mais caros. A soma dispendida chegou a $20 \$ 540$ réis nos meses de julho e agosto de 1875. De outro lado, Miguel mulato comprou dois metros de americano, um carretel de linha, um par de meias, uma escova para roupa, uma manta de lã, um xale de algodão, 4 metros de chita, uma camisa feita de morim, 3,5 metros de canga, 6,8 metros de chita, 1 chapéu de manilha, 1 vela de cera e uma lata de pólvora. A quantia dispendida por Miguel chegou a 34\$650 réis, destacando o chapéu de luxo que consumiu $13 \$ 000$ réis.

Os produtos da terra também assumiram destaque no consumo dos cativos, como a carne (6 casos), fumo ( 3 vezes), aguardente ( 9 ocorrências) e café (4 lançamentos). O escravo que mais comprou carne foi Alcencio, que adquiriu cerca de 33 quilos de carne em três negócios. Miguel mulato comprou, em duas vezes, um total de 180 gramas de fumo. A aguardente foi adquirida por 5 escravos, apenas dois mais de uma vez. Por fim, o café foi comprado por 3 escravos, somando 12,2 quilos. Todos os produtos da terra alcançaram vinte e dois lançamentos, mas apenas $37 \$ 360$ réis em valor. Destarte, notamos um leque muito variado de produtos manufaturados e da terra que eram adquiridos pelos escravos. 


\section{Liberdade}

A conquista da liberdade não era para todos os escravos. Muitos tentavam, apenas alguns conseguiam. Na história dos escravos correntistas da loja em 1875-76, pudemos acompanhar algumas trajetórias. Vamos ilustrar esses caminhos com as histórias que conseguimos reconstruir. Diversos escravos, por meio de intermediários, dirigiram-se à Junta Classificadora de Escravos para a libertação pelo Fundo de Emancipação, oferecendo seus pecúlios para facilitar a alforria. Em 1876, 8 escravos colocaram seus pecúlios em favor da sua liberdade, muitos intermediados pelos seus próprios escravagistas. ${ }^{50}$ A soma das quantias em oferta totalizou 2:150\$000 réis, perfazendo uma média de $268 \$ 750$ réis por escravo. Desse modo, acumulou-se volume substantivo de recursos no município.

O escravo Domingos de Custódio Pinto de Sampaio era um desses escravos. Apesar de ele movimentar recursos significativos, o seu saldo do período 1875-76 foi de apenas 87 mil réis a seu favor. Entretanto, ele possuía $300 \$ 000$ réis para a sua liberdade. ${ }^{51} \mathrm{O}$ dinheiro foi depositado em mãos de João Machado Pacheco no dia 31 de outubro de 1876, que deveria pagar um prêmio de $6 \%$ ao ano. Custódio aceitou a oferta de $550 \$ 000$ em junho de 1878 , recebendo do cativo $328 \$ 500$ de pecúlio e juros até essa data. Assim, Domingos alcançou a sua liberdade.

José Mendes Ouriques procurou a Junta de Classificação de Escravos para libertação pelo Fundo de Emancipação em 1882. ${ }^{52}$ Ele ofereceu Joaquim, de 56 anos, que era seu escravo pelo menos desde a matrícula de 1872 . $\mathrm{O}$ cativo era casado com mulher livre sem filhos, que consistia em prioridade para a emancipação pelo fundo. O escravagista pediu $500 \$ 000$ réis de indenização pela alforria. O coletor membro da Junta achou a avalição excessiva, assim, pediu a nomeação de avaliadores. Um dos avaliadores estabeleceu o valor de $150 \$ 000$ réis, mas outro em $180 \$ 000$. O terceiro concordou com o segundo. Assim, Joaquim ganhou sua liberdade em 1882. ${ }^{53}$

\footnotetext{
50 Autos de requerimento de liberdade a Junta Classificadora - APHT, Pasta 39.

${ }^{51}$ No livro contábil o valor de 370 mil réis foi depositado em 20 de setembro de 1875 . Talvez, uma parte dele tenha sido gasto entre as duas datas.

52 Arbitramento. APHT, Pasta 39.

$53 \mathrm{O}$ pequeno saldo a seu favor nos lançamentos da loja de João Machado Pacheco não foi mencionado no processo.
} 
José Ignácio de Faria tinha seis filhos e, já enfermo, libertou seu escravo: "Manoel, de cor preta, africano, que lhe concedo liberdade em atenção o ter-me servido bem. " O escravo não negociou com a loja no período 1875 76. Mais adiante, referiu-se à Felicidade, sua antiga escrava, que morava próximo a sua casa e lhe ajudava na doença:

Deixo de esmola a preta forra Felicidade Rosa de Jesus, que me tem acompanhado e servido com desvelado cuidado na minha longa enfermidade, dez braças de terras de frente, que a faz ao Rio Tubarão, onde é minha residência, e ligadas as que já lhe pertencem por compra que fez-me, e lhe deixo mais as terras que se acharem nos fundos das que lhe vendi, de forma que tanto estas como as ditas dez braças, irão com fundos até as divisas das terras dos herdeiros do finado meu irmão Polycarpo. (Testamento de José Ignácio de Faria, 1884, 1verso e 2).

Felicidade era escrava e transacionava com a loja de João Machado Pacheco, de acordo com as anotações do livro em estudo nesta pesquisa. Não sabemos como conseguiu a sua liberdade, mas ela tornou-se proprietária de terras por compra e doação. Outrossim, a trajetória desses três libertos não parece ser exclusiva deles, pois outros escravos em análise também podem ter trilhado o caminho da liberdade nesse período, mas não conseguimos verificar nas fontes consultadas.

Dos 16 escravos que mantiveram contas correntes na casa comercial de João Machado Pacheco e movimentaram valores no período de pouco mais de um ano, quatro conseguiram acumular saldos positivos a seu favor. Os pecúlios acumulados e os recursos da Junta de Libertação permitiram que pelo menos dois alcançassem a liberdade nos anos seguintes. Isto não impediu que outras formas de concessão de alforria pudessem ocorrer, como a gratuita por seus escravagistas. De fato, muitos escravos negociavam com a loja, porém, poucos conseguiam acumular pecúlios significativos e um subgrupo ainda menor alcançava a liberdade com seus próprios recursos. 


\section{Considerações finais}

Em pouco mais de um ano, dezesseis escravos realizaram operações de débito ou crédito em suas contas correntes numa casa de negócio, dentre outras que existiam no município, possivelmente representativa das demais lojas, como a do primeiro sogro de João Machado Pacheco. Os cativos efetuaram mais de uma centena e meia de transações nesse curto momento iluminado pelo livro contábil. Isto apontou para uma profusão grande desses negócios dos escravos.

Os cativos movimentavam, muitas vezes, dinheiro em valores substantivos para seus proprietários e também compravam um leque amplo de bens, desde vestuário, utensílios e alimentos. Para saldar seus débitos, os cativos vendiam produtos agrícolas para a casa, como feijão e principalmente mi1ho. Embora existisse concentração das quantias transacionadas nas mãos de um escravo, os volumes negociados eram consideráveis, alcançando quase dois contos de réis tanto em termos de créditos como de débitos. Assim, mantinham uma economia de significativa expressão na região.

Em geral, mercadores e casas comerciais realizavam, regularmente, operações em dinheiro para clientes, atuando por meio do adiantamento de recursos e de créditos a favor dessas pessoas. Além disso, eles facilitavam os acertos dos negócios entre os seus clientes, como fosse um intermediário que viabiliza a transferência de valores. No caso em questão, os escravos também efetuaram todas as três espécies de operações em dinheiro, desde o adiantamento, o saldo positivo e a transferência. As negociações monetárias foram muito expressivas, principalmente por meio de saques em dinheiro e pagamento a terceiros, mormente aos seus senhores. Não obstante um leque variado de operações com mercadorias e dinheiro, os saldos das operações alcançaram montantes muito menores em relação ao conjunto total de débitos e créditos transacionados nesse pouco mais de um ano. Isto demonstrou, para a maioria, uma capacidade de manter sua credibilidade para a continuidade dos negócios com a casa comercial, embora apenas uma pequena parte deles alcançasse condições de formar pecúlio e ainda menos pessoas de sonhar com a liberdade. 


\section{Fontes}

Arquivo Público e Histórico de Tubarão. Livro Diário de João Machado Pacheco (1875-76).

Brasil. Comissão Encarregada da Revisão da Tarifa das Alfandegas do Império. Documentos estatísticos sobre o comércio do Império do Brasil nos anos de 1845-1849. Rio de Janeiro: Typographia Nacional, 1853.

Coutinho, João José. Relatório do presidente da província de Santa Catarina. S.ed. 1855.

Sauer, Arthur. Almanak Administrativo, mercantil e industrial do Império do Brasil para 1885. Rio de Janeiro: Laemmert \& C., 1885.

Silva, João Thomé da. Fala dirigida à Assembleia Legislativa Provincial de Santa Catharina em 21 de março de 1875 pelo exm. sr. presidente da província, dr. João Thomé da Silva. Desterro: Typ. de J. J. Lopes, 1875.

\section{Referências}

Almeida, Carla Maria Carvalho de. Ricos e pobres em Minas Gerais: produção e hierarquização social no mundo colonial, 1750-1822. Belo Horizonte: Argvmentuvm, 2010.

Avé-Lallemant, Robert. Viagens pelas províncias de Santa Catarina, Paraná e São Paulo (1858). Belo Horizonte/ São Paulo: Itatiaia/Edusp, 1980.

Cardoso, Ciro Flamarion S. Escravo ou camponês? O protocampesinato negro nas Américas. São Paulo: Brasiliense, 1987.

Dauwe, Fabiano. A libertação gradual e a saída viável: os múltiplos sentidos da liberdade pelo fundo de emancipação de escravos. Dissertação (Mestrado em História) - UFF, 2004.

Dean, Warren. Rio Claro: um sistema brasileiro de grande lavoura: 1820-1920. São Paulo: Paz \& Terra, 1977.

Frank, Zephyr L. Dutra's world: wealth and Family in Nineteenth-century Rio de Janeiro. Albuquerque: University of New Mexico Press, 2004.

Goularti Filho, Alcides. Formação econômica de Santa Catarina. Florianópolis: Cidade Futura, 2002.

Graham, Richard. Alimentar a cidade: das vendedoras de rua à reforma liberal (Salvador, 1780-1860). São Paulo: Companhia das Letras, 2013.

Guimarães, Elione. "Experiências econômicas de cativos (Zona da Mata de Minas Gerais, segunda metade do oitocentos)." in Campos em disputa: história agrária e companhia, orgs. Guimarães, Elione \& Motta, Márcia Maria Menendes, 217-244. São Paulo: Annablume/Núcleo de Referência Agrária, 2007.

Guimarães, Elione. Terra de preto: usos e ocupação da terra por escravos e libertos (Vale do Paraíba mineiro, 1850-1920). Niterói: EDUFF, 2009.

Hillard, Katrhleen M. Masters, slaves, and exchange: power's purchase in the Old South. New York: Cambridge University Press, 2014.

Hübener, Laura Machado. O comércio da cidade do Desterro no século XIX. Florianopólis: Editora da UFSC, 1981.

Karasch, Mary C. A vida dos escravos no Rio de Janeiro, 1808-1850. São Paulo: Companhia das Leras, 2000.

Lima, Henrique Espada. Sob o domínio da precariedade: escravidão e os significados da liberdade de trabalho no século XIX. Topoi. Rio de Janeiro, v.6, n. 11, jul./dez 2005, 289-326.

Lúcio, Paulo Henrique. A escravidão em Santa Catarina: um jogo de dominação e intolerância na região de Tubarão. Dissertação (Mestrado em Educação) UNISUL, 2006.

Messias, Rosane Carvalho. Fazenda Palmital: da escravidão ao trabalho livre, 1885-1888. Anais do VI Congresso Brasileiro de História Econômica. Conservatória: ABPHE, 2005.

Paiva, Eduardo França. Escravos e libertos na Minas Gerais do Século XVIII: estratégias de resistência através dos testamentos. São Paulo: Annablume, 1995.

Estud. Econ., São Paulo, vol.50 n.2, p.293-319, abr.-jun. 2020 
Papali, Maria Aparecida. Senhores e seus escravos: querelas jurídicas em uma pequena cidade do Vale do Paraíba nas décadas de 1870/1880 São José dos Campos SP. XXVII Simpósio Nacional de História. Natal: ANPUH, 2013. $<<$ http://www.snh2013.anpuh.org/resources/anais/27/1364502183 ARQUIVO_TRABALHOCOMPLETOSENHORESESEUSESCRAVOS.pdf $>>$ visitado em 20 de maio de 2019.

Penna, Clemente Gentil. Escravidão, Liberdade e os arranjos de trabalho na Ilha de Santa Catarina nas últimas décadas de escravidão (1850-1888). Dissertação (Mestrado em História) CFCS/UFSC, 2005.

Piazza, Walter F. O escravo numa economia minifundiária. Florianópolis: UDESC, 1975.

Saraiva, Luiz Fernando e Oliveira, Thiago Alvarenga de. “A Caixa Econômica do Rio de Janeiro, 1831-1859” in Historia bancaria y monetária de América Latina (siglos XIX y XX): nuevas perspectivas, ed. Marichal, Carlos \& Gambi, Thiago, 429-462. Santander/Alfenas: Editorial de la Universidad de Cantabria/Universidade Federal de Alfenas, 2017.

Saraiva, Luiz Fernando e Freire, Jonis. “'Pertence a liberta Firmina, 09 de maio de 1888': relações de crédito na transição do trabalho escravo para o libre em uma região cafeeira - Zona da Mata Mineira." in Crédito \& Descrédito: relações sociais de empréstimos na América - séculos XVIII ao XX, orgs. Saraiva, Luiz Fernando \& Guimarães, Carlos Gabriel, 282-317. Niteroi: Eduff/Faperj, 2018.

Schwartz, Stuart B. Segredos internos: engenhos e escravos na sociedade colonial. São Paulo: Cia. das Letras/ CNPq, 1988.

Soares, Luiz Carlos. Os Escravos ao ganho no Rio de Janeiro do século XIX. Revista Brasileira de História. São Paulo, v. 8, nº 16, 1988. 107-42.

Valencia Villa, Carlos Eduardo. La producción de la libertad: economia de los escravos manumitidos em Río de Janeiro a mediados del siglo XIX. Bogotá: ICANH, 2011.

Xavier, Regina Célia Lima. A conquista da liberdade: libertos em Campinas na segunda metade do século XIX. Campinas: CMU/UNICAMP, 1996. 


\section{ANEXOS}
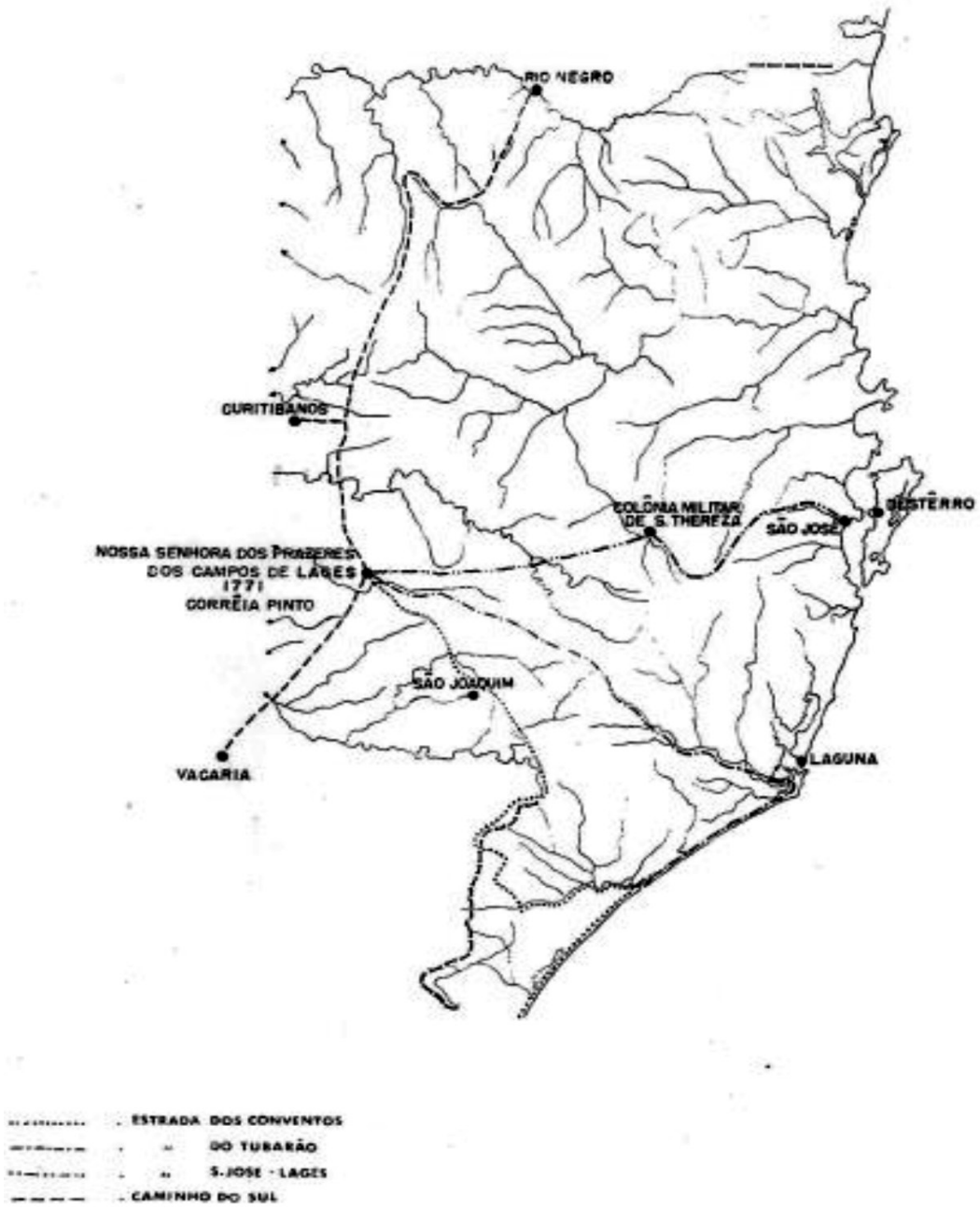

Mapa 1 - Mapa dos caminhos de tropas em Santa Catarina

Fonte: PIAZZA, Walter. Atlas Histórico do Estado de Santa Catarina. Florianópolis: Departamento de Cultura da Secretaria de Educação, 1970. 


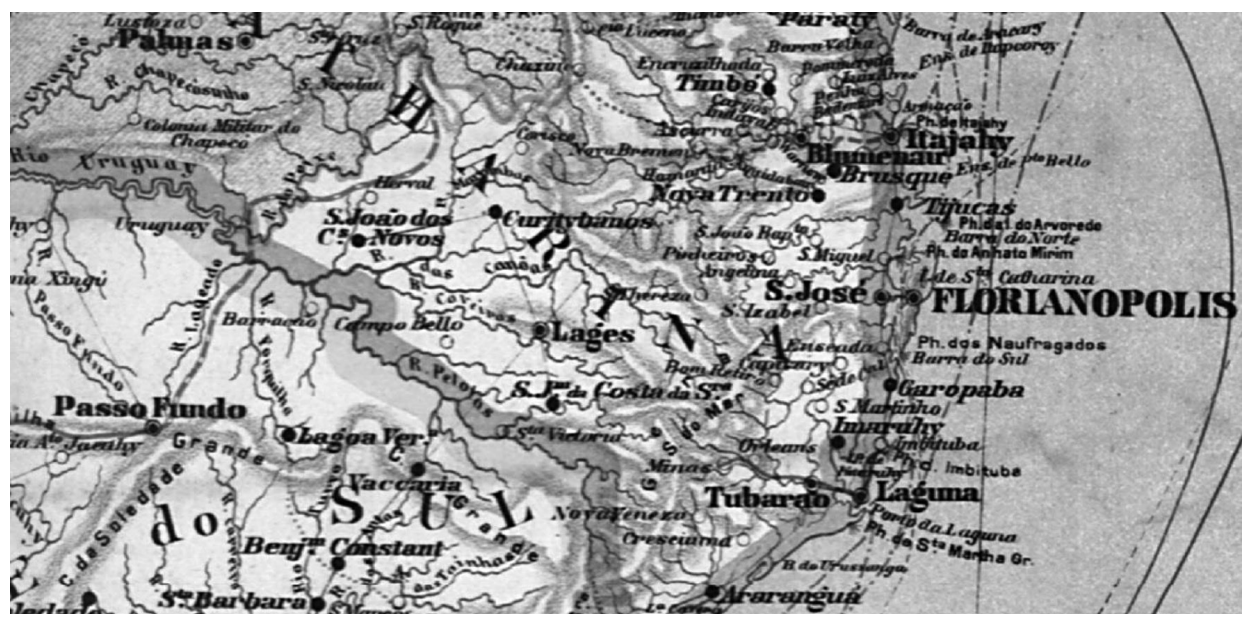

Mapa 2 - Mapa de Santa Catarina em 1908

Fonte: Companhia Lithographica Hartmann-Reichenbach, depositado na Library of Congress Geography and Map Division Washington, D.C. 20540-4650 dcu http://hdl.loc.gov/loc.gmd/g5400.ct000637 


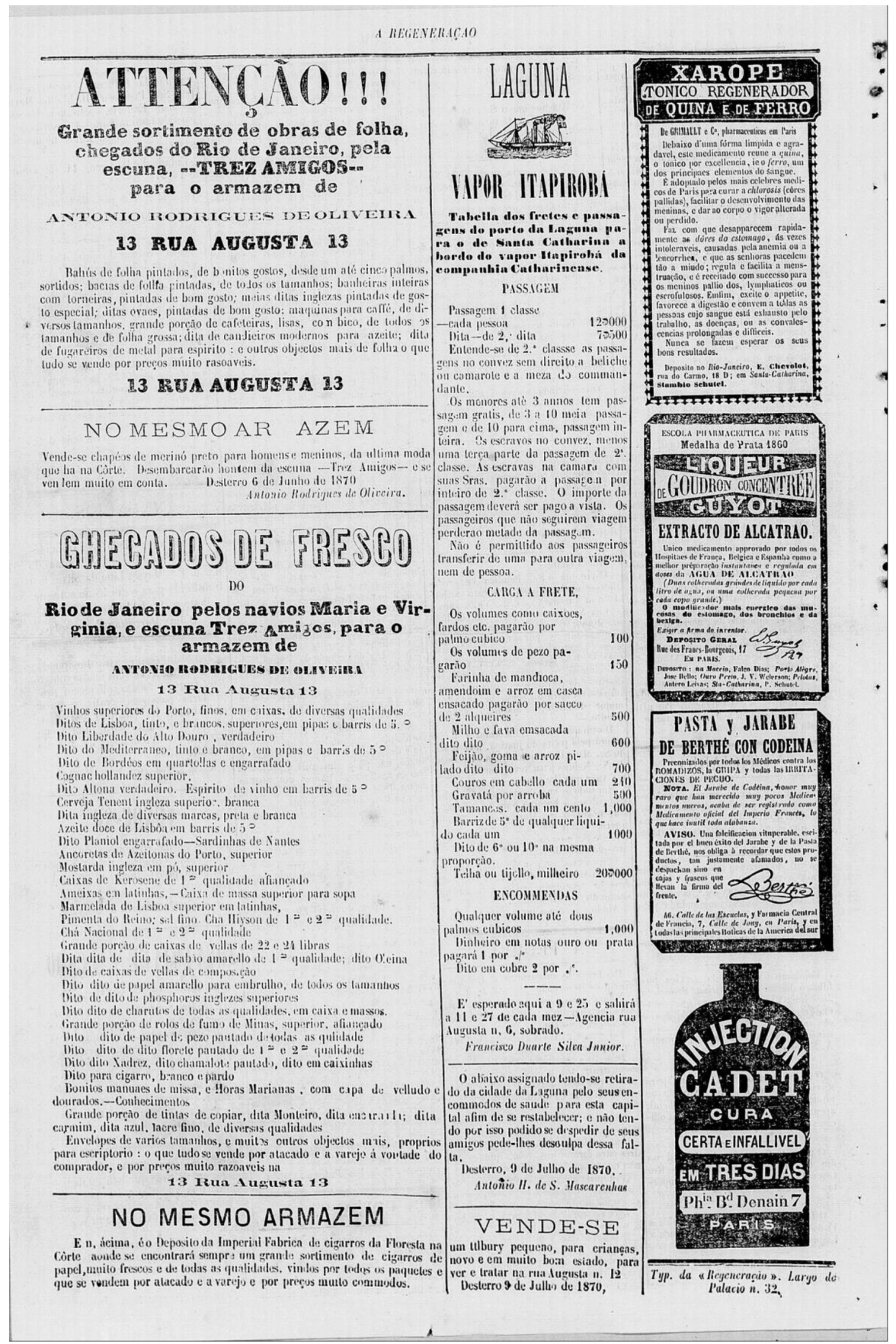

Figura 1 - A Regeneração, 14 de julho de 1870, p. 4. 